\title{
Low-Dose UVA Radiation-Induced Adaptive Response in Cultured Human Dermal Fibroblasts
}

\author{
Zhongrong Liu, Hulin Chen, Huilan Yang, Jie Liang, and Xuemei Li \\ Department of Dermatology, Guangzhou General Hospital of Guangzhou Military Command (Liuhuaqiao Hospital), \\ Guangzhou 510010, China \\ Correspondence should be addressed to Zhongrong Liu, pfklzr@163.com
}

Received 12 February 2012; Revised 6 April 2012; Accepted 3 May 2012

Academic Editor: Timon Cheng-Yi Liu

Copyright (๑) 2012 Zhongrong Liu et al. This is an open access article distributed under the Creative Commons Attribution License, which permits unrestricted use, distribution, and reproduction in any medium, provided the original work is properly cited.

Objective. To investigate the mechanism of the adaptive response induced by low-dose ultraviolet A (UVA) radiation. Methods. Cultured dermal fibroblasts were irradiated by a lethal dose of UVA $\left(86.4 \mathrm{~J} / \mathrm{cm}^{2}\right)$ with preirradiation of single or repetitive low dose of UVA $\left(7.2 \mathrm{~J} / \mathrm{cm}^{2}\right)$. Alterations of cellular morphology were observed by light microscope and electron microscope. Cell cycle and cellular apoptosis were assayed by flow cytometer. The extent of DNA damage was determined by single-cell gel electrophoresis (SCGE). Results. The cultured dermal fibroblasts, with pretreatment of single or repetitive irradiation of $7.2 \mathrm{~J} / \mathrm{cm}^{2}$ UVA relieved toxic reaction of cellular morphology and arrest of cell cycle, decreased apoptosis ratio, reduced DNA chain breakage, and accelerated DNA repair caused by subsequent $86.4 \mathrm{~J} / \mathrm{cm}^{2}$ UVA irradiation. Compared with nonpretreatment groups, all those differences were significant $(P<0.01$ or $P<0.05)$. Conclusions. The adaptation reaction might depend on the accumulated dose of low-dose UVA irradiation. Low-dose UVA radiation might induce adaptive response that may protect cultured dermal fibroblasts from the subsequent challenged dose of UVA damage. The duration and protective capability of the adaptive reaction might be related to the accumulated dose of low-dose UVA Irradiation.

\section{Introduction}

All the organisms on the Earth are constantly under the impact of environment. Generally, the organisms adapt to the various environmental factors by natural selection. The nature of adaptive response depends upon the different environmental factors, subject to the evolutionary development and functional status of the organisms, while a few others depend on the nature and the dose of the environmental factors [1].

The lethal dose of the environmental factors often leads to serious injury, or even death of the organisms. However, when the intensity of the environmental factor was not lifethreatening, it might induce an adaptive response to reduce the damage caused by a subsequent attack by a lethal dose of the same factor within a certain duration. The nature of the adaptive response to low intensity or dose of the environmental factors is one of the hot areas of research [2].

The adaptive response of organisms or cells induced by low-dose ionization radiation (IR), also termed as low-dose radiation hormesis, was described as the reduced damaging effect of a lethal radiation dose when pretreated by a low priming dose [3]. In the last 30 years, the adaptive response to low-dose IR has been widely investigated. It has been observed in vitro and in vivo using various indicators of cellular damage, such as cell lethality, chromosomal aberrations, mutation induction, radiosensitivity, and DNA repair [4-6], although its precise mechanisms remained to be further elucidated. All the ubiquitous adaptive response phenomena entail the conservation of programmed adaptability of organic evolution [7].

The Sun emits a wide spectrum of electromagnetic waves from IR to microwaves. Photobiomodulation (PBM) of laser irradiation or monochromatic light (LI) were widely studied as well [8]. Several observations showed that even low-energy visible light (LEVL) might recover the rate of healing of wounds or bone defects $[9,10]$, the fertilizing capability of sperm cells [11], and proliferation of cultured cells such as fibroblasts [12], keratinocytes [13], and lymphocytes [14].

Although exposure to ultraviolet (UV) light is often viewed as pathogenic owing to its role in the genesis of skin cancer and skin aging [15-17], growing epidemiological 
evidence suggests that such exposure may decrease the risk for a number of more serious cancers. Aside from having a favorable impact on blood pressure and vascular health, it may help to prevent certain autoimmune disorders, in addition to its well-known influence on bone density [18, 19]. These beneficial effects may relate to the adaptive response of UV radiation.

It has been widely reported that high doses of UV radiation induce cellular adaptive response, including photoreactivation, UV damage excision repair (UVER) [20], recombination repair, and SOS reaction [21]. The thickening and pigmentation of the epidermis caused by long-term UV radiation are regarded as a type of adaptive response of the organisms against UV radiation [22, 23]. However, the adaptive response induced by low-dose UV radiation has yet to be fully investigated.

As the major component of solar UV, UVA (320 $400 \mathrm{~nm}$ ) mainly produces reactive oxygen species (ROS) through interaction with endogenous photosensitizers. These ROS in turn damage DNA (indirect DNA damage), proteins and membranes [24]. Through direct damage to tissue cells and proteins, and the induction of proteolytic pathways, UVA causes cellular damage similar to IR [25]. However, whether the low-dose UV radiation induces adaptive response like low-dose IR will be investigated in this paper.

\section{Material and Methods}

2.1. Fibroblast Culture. The cell culture media and chemicals were purchased from Gibco Life Technologies (Cergy Pontoise, France) and Sigma (St. Louis). Skin specimens were collected from healthy neonatal foreskin, and primarily cultured with basal medium (DMEM medium containing 10\% fetus calf serum (FCS), $10 \mathrm{mM} \mathrm{N}-2$ HEPES, $1.5 \mathrm{~g} / \mathrm{L}$ sodium bicarbonate, $0.3 \mathrm{~g} / \mathrm{L}, 100 \mathrm{U} / \mathrm{mL}$ glutamine, penicillin, and $100 \mu \mathrm{g} / \mathrm{mL}$ streptomycin). Cells were maintained at $37^{\circ} \mathrm{C}$ in $5 \% \mathrm{CO}_{2}, 95 \%$ air in a humidified chamber, and then dermal fibroblasts were harvested successfully and stocked in nitrogen canister based on the methods used to establish diploid cell lines [26].

2.2. UVA Irradiation and Low-Dose Determination. Human dermal fibroblasts were thawed and inoculated (250,000 cells/dish), and grown to $70 \%$ confluence in a $10-\mathrm{cm}$ plastic culture dish (Corning Costar, Cambridge, MA, USA). To avoid toxicity induced by UV exposure of the culture medium, irradiation was achieved in PBS (phosphate buffered saline, $0.01 \mathrm{mM}, \mathrm{pH} 7.2$ ). The cells were then exposed under desktop device (Sigma Aldrich), which releases UVA. UVA intensity was $60 \mathrm{~mW} / \mathrm{cm}^{2}$ at $15 \mathrm{~cm}$ exposure distance. The dosage of single exposure was calculated by UVA intensity $\left(\mathrm{mW} / \mathrm{cm}^{2}\right) \times$ time $(\mathrm{s})$. After irradiation, the PBS was removed and the fibroblasts were incubated in the medium at $37^{\circ} \mathrm{C}$ and $5 \% \mathrm{CO}_{2}$ for varying durations. Control cells were treated similarly but without irradiation [27].

Cytotoxicity of UVA irradiation and low-dose modulation were assessed by MTT (3-(4,5-dimethylthiazol-2-yl)2,5-diphenyltetrazolium bromide). Cultured dermal fibroblasts were transferred into 96-well plates with a density of
$1 \times 10^{3}$ cells/well, and irradiated by different doses of UVA $\left(0,7.2,14.4,28.8,43.2,64.8,86.4\right.$, and $\left.108 \mathrm{~J} / \mathrm{cm}^{2}\right)$. Each radiation group had 6 repeated wells. Cells in the control group were covered with a tin foil. At the six different time points of $3 \mathrm{~h}, 6 \mathrm{~h}, 12 \mathrm{~h}, 24 \mathrm{~h}, 48 \mathrm{~h}$, and $72 \mathrm{~h}$ after irradiation, MTT solution $\left(5 \mathrm{~g} / \mathrm{L}, 20 \mu \mathrm{L}, 4^{\circ} \mathrm{C}\right)$ was added to each well and the plate was incubated for $4 \mathrm{~h}$. Subsequently, the medium was discarded, and $150 \mu \mathrm{L}$ dimethylsulfoxide (DMSO) was added into each well. After shaking for $10 \mathrm{~min}$, the absorbance value at the wavelength of $570 \mathrm{~nm}\left(A_{570}\right)$ was determined by Microplate EL 309 Reader. The survival rate (\%) was calculated as $\left[\left(A_{570}\right.\right.$ of the sample $-A_{570}$ of the blank $) /\left(A_{570}\right.$ of the control $-A_{570}$ of the blank) $] \times 100 \%[28,29]$.

2.3. Experimental Groups. Cells cultured for $5 \sim 10$ generations were divided into 4 groups as follows (Table 1): shamirradiated group (SIG), normal cultured cells with the same number of doublings compared with the irradiation group were sham irradiated after similar manipulation; low-dose group (LDG), the cultured cells irradiated by $7.2 \mathrm{~J} / \mathrm{cm}^{2}$ UVA $\left(60 \mathrm{~mW} / \mathrm{cm}^{2}\right.$ for $\left.120 \mathrm{~s}\right)$ once a day were divided into LDG1 to LDG5 according to the different accumulated doses 7.2, $14.4,28.8,57.6$, and $115.2 \mathrm{~J} / \mathrm{cm}^{2}$, respectively; high-dose group (HDG), the cultured cells were only irradiated by $86.4 \mathrm{~J} / \mathrm{cm}^{2}$ UVA $\left(60 \mathrm{~mW} / \mathrm{cm}^{2}\right.$ for $\left.1440 \mathrm{~s}\right)$; adaptive response group (ARG), the cultured cells preirradiated by low-dose UVA, and then irradiated by high-dose $86.4 \mathrm{~J} / \mathrm{cm}^{2} \mathrm{UVA}$. The cells were also divided from ARG1 to ARG5 according to the different accumulated low doses of UVA: 7.2, 14.4, 28.8, 57.6, and $115.2 \mathrm{~J} / \mathrm{cm}^{2}$, respectively, and then irradiated by high dose of $86.4 \mathrm{~J} / \mathrm{cm}^{2}$ UVA after preirradiation for $6 \mathrm{~h}, 12 \mathrm{~h}, 24 \mathrm{~h}$, $48 \mathrm{~h}, 72 \mathrm{~h}, 7 \mathrm{~d}$, and $14 \mathrm{~d}$, respectively.

2.4. Morphological Observations. Cellular and morphological alterations in different groups were observed at different times under inverted transmission electron microscopy (TEM, JEM-2000EX, Japan) and scanning electron microscopy (SEM, S-520, Japan). Alterations of superficial membrane microvilli and intracellular mitochondria were prominently identified.

2.5. Detection of Cell Cycle and Apoptosis with Flow Cytometry. Cells cultured for $5 \sim 10$ generations were inoculated into a 6-well culture plate by different grouping manipulations, rinsed once with $1 \mathrm{~mL}$ D-Hank's liquid, digested with $0.25 \%$ dispase, and then centrifuged and supernatant removed. Cells were separated with $0.5 \mathrm{~mL}$ D-Hank's and rinsed twice with $0.01 \mathrm{M}$ PBS ( $\mathrm{pH}$ 7.4). Cell suspension was prepared with $190 \mu \mathrm{L}$ binding buffer and the density adjusted to $1 \times$ $10^{6} / \mathrm{mL}$. Annexin V-FITC and PI $(1 \mu \mathrm{g} / \mathrm{mL})$ were added to the cell suspension. Cells were stored for $10 \mathrm{~min}$ away from light and rinsed once with binding buffer. Cell cycle and apoptosis were assayed by flow cytometer (FCM). (Elite ESP flow cytometry, Beckman Coulter, Inc.). FCM analysis was done using a single argon ion laser. The wavelength of excited light was $488 \mathrm{~nm}$, and the wavelengths of emitted light were 515-545 nm for annexin V-FITC and 563-607 nm for DNAPI. Each specimen was measured using 15000 to 20000 cells. 
TABLE 1: UVA intensity, exposure time, and dosage.

\begin{tabular}{|c|c|c|c|c|}
\hline \multicolumn{2}{|l|}{ Experiment grouping } & Intensity $\left(\mathrm{mW} / \mathrm{cm}^{2}\right)$ & Exposure time (s) & Dosage $\left(\mathrm{J} / \mathrm{cm}^{2}\right)$ \\
\hline \multicolumn{2}{|c|}{ Shamed irradiation group (SIG) } & 0 & 0 & 0 \\
\hline \multicolumn{2}{|c|}{ High-dose group (HDG) } & 60 & 1440 & 86.4 \\
\hline \multirow{5}{*}{ Low-dose group (LDG) } & LDG1 & \multirow{5}{*}{60} & $120 \times 1$ & 7.2 \\
\hline & LDG2 & & $120 \times 2$ & 14.4 \\
\hline & LDG3 & & $120 \times 3$ & 28.8 \\
\hline & LDG4 & & $120 \times 4$ & 57.6 \\
\hline & LDG5 & & $120 \times 5$ & 115.2 \\
\hline \multirow{10}{*}{ Adaptive response group (ARG) } & \multirow{2}{*}{ ARG1 } & \multirow{10}{*}{60} & $120 \times 1 \mathrm{~s}$ for preirradiation & 7.2 (preirradiated dose) \\
\hline & & & $1440 \mathrm{~s}$ for challenged irradiation & 86.4 (challenged dose) \\
\hline & \multirow{2}{*}{ ARG2 } & & $120 \times 2 \mathrm{~s}$ for pre irradiation & 14.4 (preirradiated dose) \\
\hline & & & $1440 \mathrm{~s}$ for challenged irradiation & 86.4 (challenged dose) \\
\hline & \multirow{2}{*}{ ARG3 } & & $120 \times 3 \mathrm{~s}$ for pre irradiation & 28.8 (preirradiated dose) \\
\hline & & & $1440 \mathrm{~s}$ for challenged irradiation & 86.4 (challenged dose) \\
\hline & \multirow{2}{*}{ ARG4 } & & $120 \times 4 \mathrm{~s}$ for pre irradiation & 57.6 (preirradiated dose) \\
\hline & & & $1440 \mathrm{~s}$ for challenged irradiation & 86.4 (challenged dose) \\
\hline & \multirow{2}{*}{ ARG5 } & & $120 \times 5 \mathrm{~s}$ for pre irradiation & 115.2 (preirradiated dose) \\
\hline & & & $1440 \mathrm{~s}$ for challenged irradiation & 86.4 (challenged dose) \\
\hline
\end{tabular}

The detection rate was about 500 cells/s. Lantastic software was used for data analysis [30].

2.6. Single-Cell Gel Electrophoresis (SCGE). According to the methods reported [27, 31], SCGE was carried out on all the experimental groups $60 \mathrm{~min}$ after UVA irradiation. Cell proportion of DNA migration was counted under the fluorescence microscope: 100 cells were counted per sample randomly, and 3 samples were observed per group. The diameter of nuclear DNA and the length of DNA migration were measured: $6 \sim 10$ cells were observed per sample randomly, and 40 cells were surveyed per group.

2.7. Statistical Analysis. Data were expressed as mean \pm standard deviation $(x \pm S)$ and analyzed by SPSS 13.0 software. One-way ANOVA was used for intergroup comparison and single factor analysis of variance was used for group comparison. $P<0.05$ was considered statistically significant.

\section{Results}

3.1. Cytotoxicity of UVA Irradiation. Spindle-shaped fibroblasts were observed after primary culture for $24 \mathrm{~h}$ to $48 \mathrm{~h}$. With continued culture, fibroblasts aggregated. The test was carried out with cells after $5 \sim 10$ passages. Fibroblasts were irradiated by UVA at $0,7.2,14.4,28.8,43.2,64.8,86.4$, and $108 \mathrm{~J} / \mathrm{cm}^{2}$, respectively. Cell survival rates were tested by MTT at $3 \mathrm{~h}, 6 \mathrm{~h}, 12 \mathrm{~h}, 24 \mathrm{~h}, 48 \mathrm{~h}$, and $72 \mathrm{~h}$, respectively, and the growth curves were drawn, respectively, as shown in Figure 1 [32].

3.2. Low-Dose UVA Preirradiation Effects on Fibroblast Synthesis and Cellular Senescence, and Its Protection against Subsequent Lethal Dose Showing. Alterations in cellular morphology and proliferation of cultured dermal fibroblasts

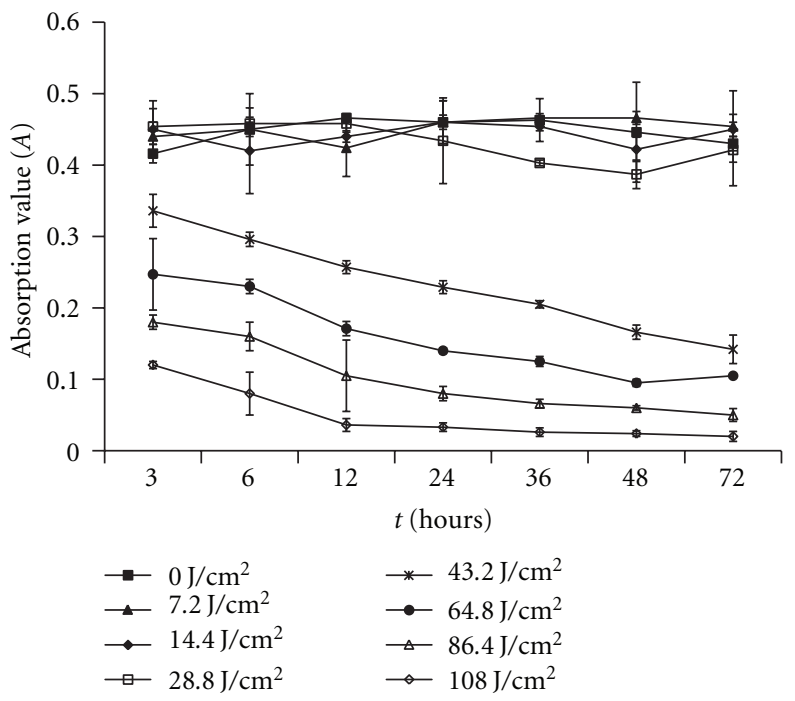

FIgURE 1: Viability of normal human fibroblasts after UVA irradiation. Normal human fibroblasts were irradiated with UVA at the indicated dosage $\left(\mathrm{J} / \mathrm{cm}^{2}\right)$, and then cell viability was determined using MTT method at the indicated time (h). No change in cell viability under $7.2,14.4$, and $28.8 \mathrm{~J} / \mathrm{cm}^{2}$ UVA irradiation was seen in comparison with the sham-irradiated cells $(P>0.05$; Oneway ANOVA) and no difference among the three dosages was seen $(P>0.05$, One-way ANOVA). Decrease in cell viability was observed with the UVA dose over $43.2 \mathrm{~J} / \mathrm{cm}^{2}$. Twenty-four hours after $86.4 \mathrm{~J} / \mathrm{cm}^{2}$ UVA treatment, cell viability only reached $19.7 \%$, in multiple comparisons with the LSD method. Significant difference among 43.2, 64.8, 86.4, and $108 \mathrm{~J} / \mathrm{cm}^{2}$ UVA irradiation was observed.

treated with single irradiation of $7.2 \mathrm{~J} / \mathrm{cm}^{2}$ UVA were not observed clearly under inverted microscope. With increasing irradiation, cells showed slight inhibition of proliferation and enlarged cell volume. At a cumulative dosage up 


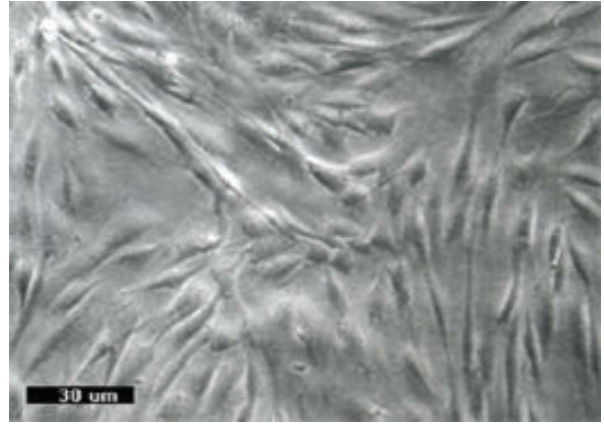

(a)

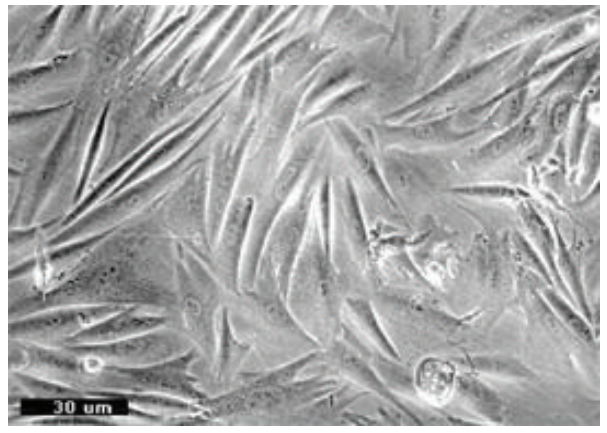

(b)

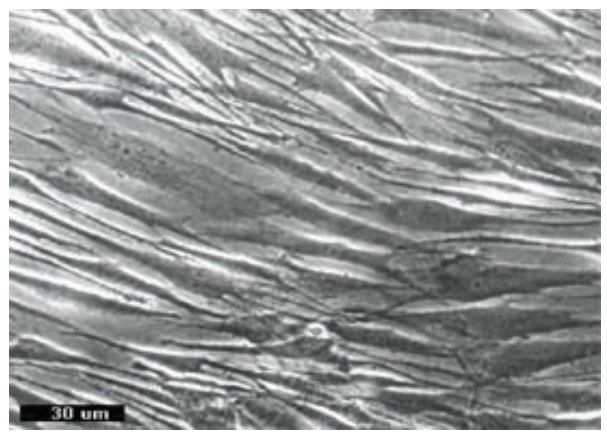

(c)

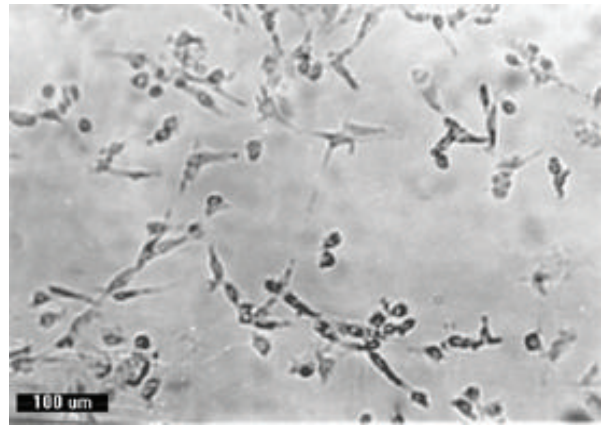

(d)

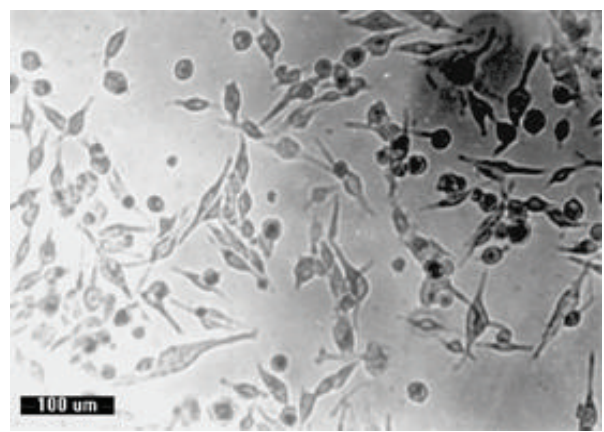

(e)

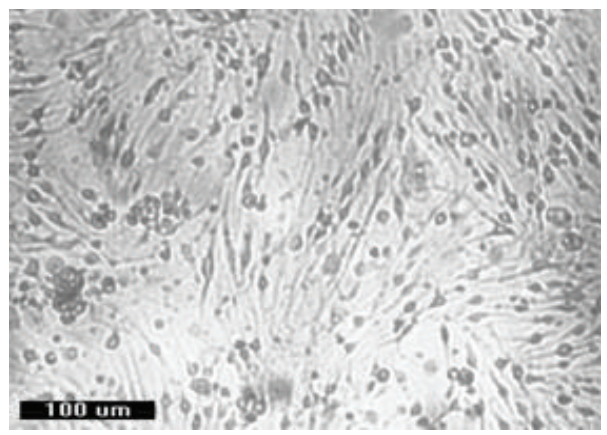

(f)

FIGURE 2: Morphological changes in cultured fibroblasts recorded by light microscopy. (a) SIG, normal fibroblasts showed active cell proliferation. (b) LDG1, single irradiation of $7.2 \mathrm{~J} / \mathrm{cm}^{2}$ UVA caused no significant effect on cell morphology and cell proliferation. (c) LDG5, repetitive irradiation of $7.2 \mathrm{~J} / \mathrm{cm}^{2} \mathrm{UVA}$ at a total dose of $115.2 \mathrm{~J} / \mathrm{cm}^{2}$ caused large cell volume, increased intracellular particles, and inhibited cell proliferation. (d) HDG, $12 \mathrm{~h}$ after $86.4 \mathrm{~J} / \mathrm{cm}^{2}$ UVA irradiation: massive apoptotic death was observed. (e) ARG1, $3 \mathrm{~h}$ after single low-dose UVA preirradiation: atomic and death of fibroblasts caused by sequential $86.4 \mathrm{~J} / \mathrm{cm}^{2} \mathrm{UVA}$ irradiation was reduced. (f) ARG5, $3 \mathrm{~h}$ after repetitive irradiation of $7.2 \mathrm{~J} / \mathrm{cm}^{2}$ UVA at a cumulative dosage of $115.2 \mathrm{~J} / \mathrm{cm}^{2}$, death of fibroblasts caused by subsequent $86.4 \mathrm{~J} / \mathrm{cm}^{2} \mathrm{UVA}$ irradiation was reduced significantly.

to $115.2 \mathrm{~J} / \mathrm{cm}^{2}$, the cells were transferred into the sixwell culture plate at $1 \times 10^{6}$ cells $/ \mathrm{mL}$. Under scanning electron microscope (SEM), normal cellular morphology was observed in the cells irradiated once with low-dose UVA. With a UVA dosage of over $28.8 \mathrm{~J} / \mathrm{cm}^{2}$, increasing and lengthening of apophysis and abundance of microvilli with normal intracellular structure were observed. Compared with normal cells, an abundance of rough endoplasmic reticulum (RER) and mitochondria were observed in the cultured fibroblasts without significant cytotoxicity. However, along with additional exposure to low-dose UVA irradiation, fibroblasts showed characteristic changes in morphology and cytology of cell senescence including delayed doubling time and enlarged volume, cellular granulation, augmented volume of mitochondria and so on. Massive apoptotic death of cultured cells irradiated with $86.4 \mathrm{~J} / \mathrm{cm}^{2}$ UVA was observed after $3 \mathrm{~h}$, reaching a peak at about $12 \mathrm{~h}$. Evidence of acute toxic reaction under SEM included membrane vacuolization, dendrite shrinkage, necrocytosis, intracellular edema, endoplasmic reticulum extension, mitochondrial edema, membrane destruction, and apoptosis (nuclear loss of volume, chromatin concentration, crescents-like nuclear formation, and microvillus of membrane vanished). In ARG, the time of acute toxic reaction was delayed with high-dose UVA irradiation after the single low-dose UVA preirradiation in two phases in $12 \mathrm{~h}(3 \mathrm{~h}, 6 \mathrm{~h})$. The degree of acute toxic 


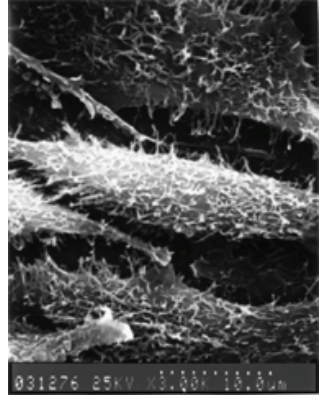

(a)

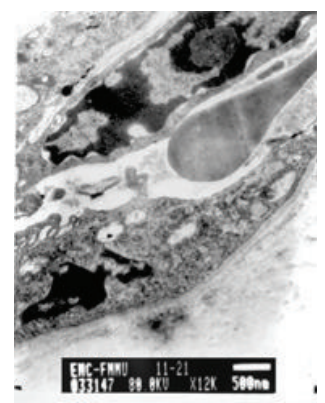

(d)

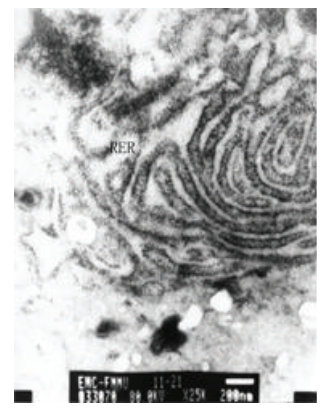

(g)

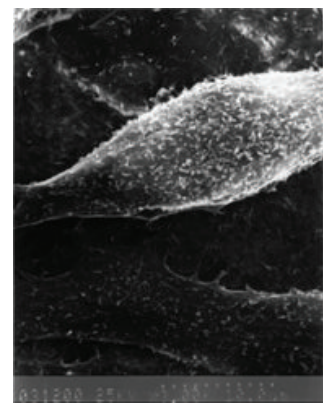

(b)

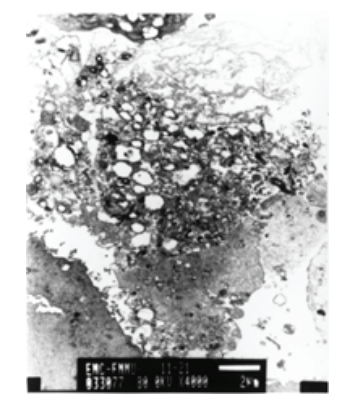

(e)

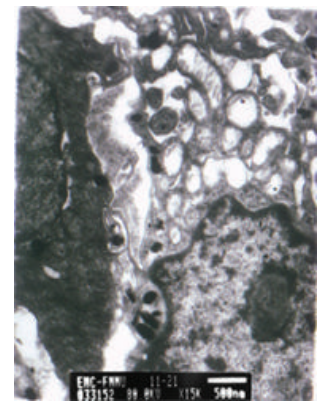

(h)

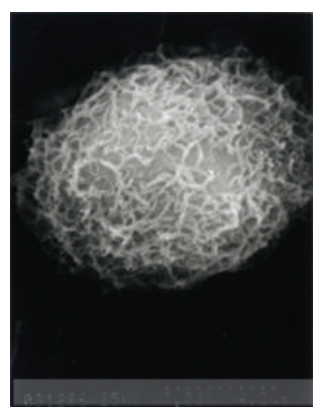

(c)

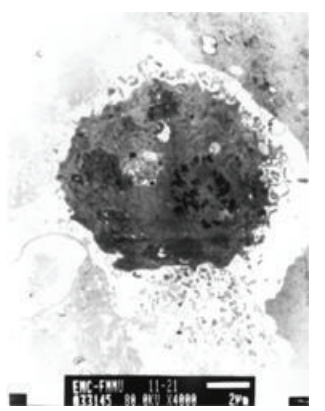

(f)

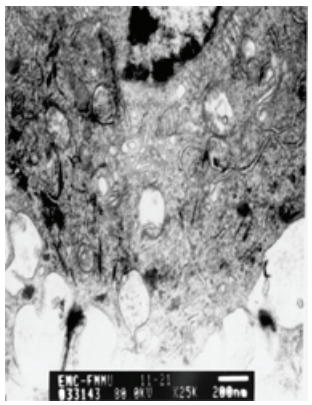

(i)

FIGURE 3: Ultrastructural changes of cultured fibroblasts. (a) SIG, normal morphology of fibroblast showed rich microvilli on cell surface (SEM). (b) HDG, $30 \mathrm{~min}$ after irradiation by $86.4 \mathrm{~J} / \mathrm{cm}^{2}$ UVA, microvilli disappeared on cell surface (SEM). (c) ARG3, preirradiated with repetitive irradiation of $7.2 \mathrm{~J} / \mathrm{cm}^{2}$ UVA for a total dosage of $28.8 \mathrm{~J} / \mathrm{cm}^{2} ; 30 \mathrm{~min}$ after irradiation by $86.4 \mathrm{~J} / \mathrm{cm}^{2} \mathrm{UVA}$, fibroblasts showed apoptosis (SEM). (d) SIG, normal morphology of fibroblast showed normal mitosis (TEM). (e) HDG, 30 min after irradiation by $86.4 \mathrm{~J} / \mathrm{cm}^{2}$ UVA, cells with vacuolization showed necrosis (TEM). (f) ARG3, preirradiated with repetitive irradiation of $7.2 \mathrm{~J} / \mathrm{cm}^{2} \mathrm{UVA}$ with a cumulative dosage of $28.8 \mathrm{~J} / \mathrm{cm}^{2}$, and then $30 \mathrm{~min}$ after irradiation by $86.4 \mathrm{~J} / \mathrm{cm}^{2} \mathrm{UVA}$, fibroblasts showed apoptosis (TEM). (g) LDG3, after irradiation with repetitive irradiation of $7.2 \mathrm{~J} / \mathrm{cm}^{2}$ UVA for a cumulative dosage of $28.8 \mathrm{~J} / \mathrm{cm}^{2}$, fibroblasts showed plenty of RER (TEM). (h) LDG3, after irradiation with repetitive irradiation of $7.2 \mathrm{~J} / \mathrm{cm}^{2}$ UVA for a cumulative dosage $28.8 \mathrm{~J} / \mathrm{cm}^{2}$, fibroblasts showed increased number of mitochondria (TEM). (i) LDG5, after irradiation with repetitive irradiation of $7.2 \mathrm{~J} / \mathrm{cm}^{2} \mathrm{UVA}$ for a cumulative dosage $115.2 \mathrm{~J} / \mathrm{cm}^{2}$, fibroblasts showed aging of mitochondria (TEM).

response was reduced under light microscope and SEM. However, the protective effects disappeared in phases at $12 \mathrm{~h}$ and $24 \mathrm{~h}$ with a lethal dose of UVA. When the low-dose UVA increased to over $28.8 \mathrm{~J} / \mathrm{cm}^{2}$, the protective effects due to alterations in cellular morphology caused by lethal-dose UVA irradiation were still apparent, even 14 days later. The changes in cellular morphology in different groups were shown in Figures 2 and 3.

\subsection{Low-Dose UVA Preirradiation Induced Fibroblast Cell} Cycle Arrest, Reduced Apoptosis due to Subsequent Lethal Dose Irradiation. In our studies, cell cycle and apoptosis of fibroblasts were detected by flow cytometry. Propidium iodide staining using single parameter histogram represented the cell cycle changes in every group. DNA histogram offered peak distribution. The ordinate represented cell number, the abscissa in the $2 \mathrm{C}$ represented diploid cells in the G0/G1 phase and in the $4 \mathrm{C}$ represented cells with DNA four times in the G2/M period. The peak distribution between $2 \mathrm{C}$ and $4 \mathrm{C}$ denoted cells with DNA, diploid to four times in S phase and that before $2 \mathrm{C}$ denoted apoptosis in cells with hypodiploid DNA [33].

The results showed that the proportion of cells increased in the G0/G1 phase and in the S phase but decreased in the 


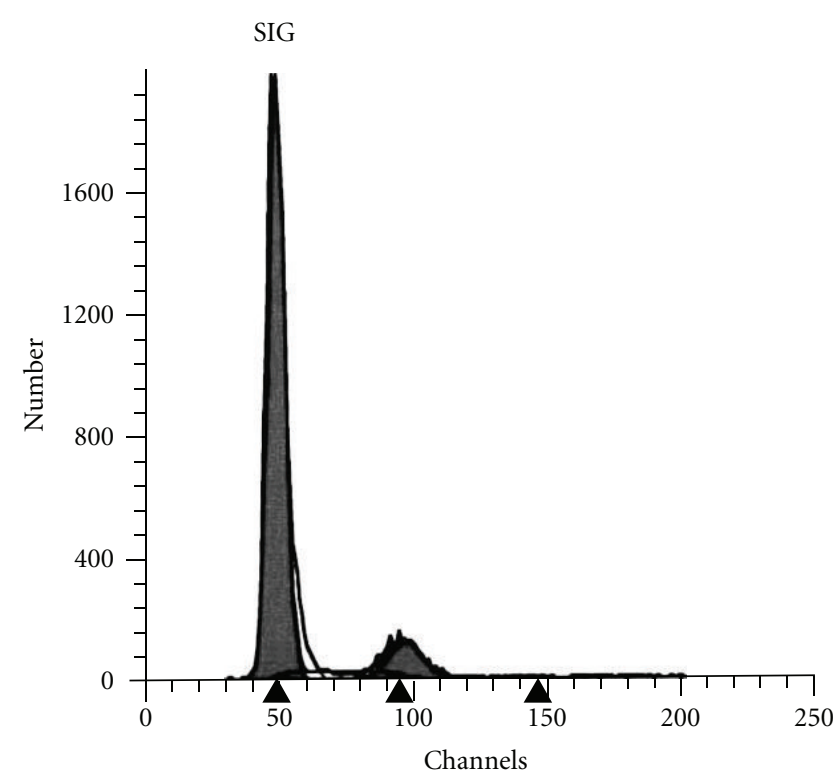

(a)

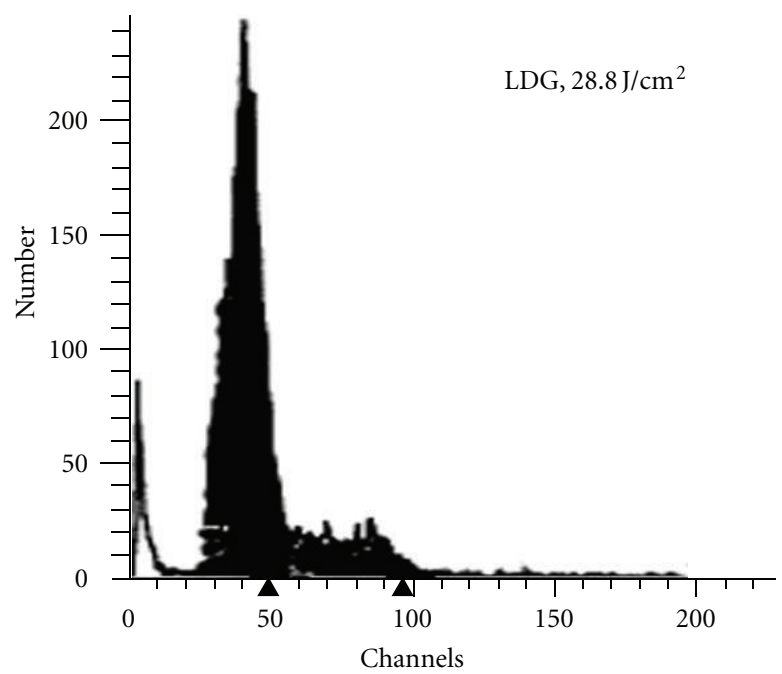

(b)

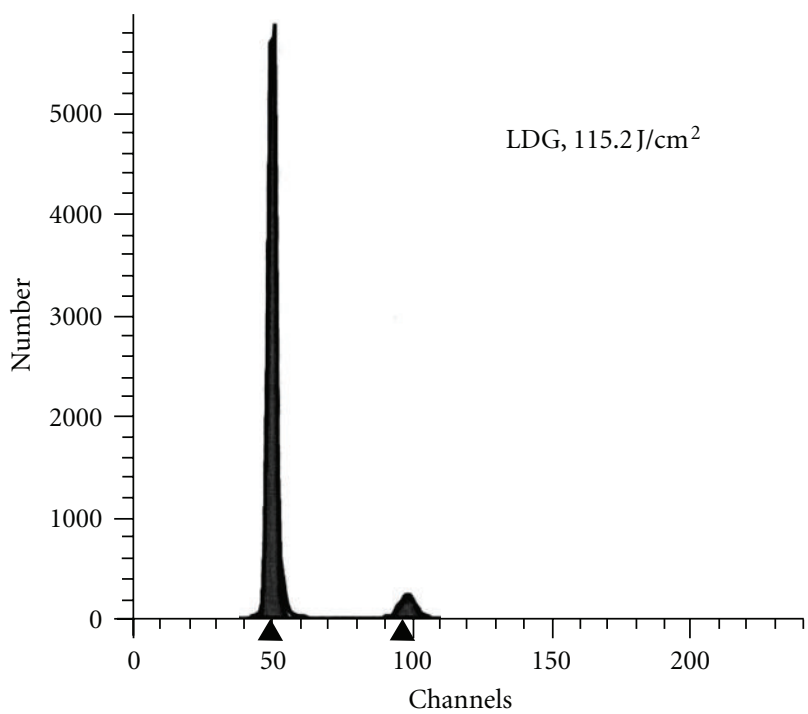

(c)

FIGURE 4: Effects of low-dose UVA on fibroblast cell cycle. PI staining using single parameter histogram represented the change of cell cycle in each group. DNA histogram offered peak distribution. The ordinates represented cell number, and the abscissa represented PI intensity. The DNA peak near 50 (2C) in the abscissa represented the diploid G0/G1 phase; the DNA peak near 100 (4C) in the abscissa represented the tetraploid G2/M phase; the DNA peak between 2C and 4C represented diploid to tetraploid S phase; the DNA peak before 2C represented hypodiploid DNA fragments indicating cell apoptosis. (a) Phase distribution of cell cycle of SIG fibroblasts. The proportions of G0/G1 phase, $\mathrm{S}$ phase, and G2/M phase were $85.01 \%, 6.49 \%$, and $8.49 \%$, respectively. (b and c) Repeated low-dose UVA irradiation altered the phase distribution of cell cycle. When the dosage accumulated to $28.8 \mathrm{~J} / \mathrm{cm}^{2}$, the proportions of G0/G1 phase, S phase, and G2/M phase were $84.09 \%, 12.95 \%$, and $1.95 \%$, respectively (b); when the dosage accumulated to $115.2 \mathrm{~J} / \mathrm{cm}^{2}$, the inhibition of cell cycle was observed apparently. The proportions of G0/G1 phase, S phase, and G2/M phase were $93.97 \%, 5.37 \%$, and $0.66 \%$, respectively (c).

G2/M phase along with the cumulative dose after irradiation with single low-dose UVA. However, all of these did not show apoptosis peak markedly and the subsequent inhibition of cell cycle. The distribution of fibroblasts in different phases of the cell cycle with different cumulative doses of low-dose UVA irradiation, are shown in Figure 4, and Table 2.

Annexin V/PI staining and two-dimensional scatter diagram showed the percentage of different cells: normal, apoptosis, injured, and dead. A dot-plot of annexin V-FITC versus PI showed four separate clusters: cells negative for Annexin V-FITC and PI were viable (left inferior quadrant), those positive for Annexin V-FITC but negative for PI were apoptotic (right inferior quadrant), those positive for Annexin V-FITC and PI were necrotic (right superior quadrant) and those negative for Annexin V-FITC but positive for PI were injured (left superior quadrant). 
TABLe 2: Effects of low-dose UVA on fibroblast cell cycle $(x \pm S \%, n=4)$.

\begin{tabular}{|c|c|c|c|c|c|c|}
\hline \multirow{2}{*}{ Group/cell cycles } & \multirow{2}{*}{ SIG } & \multicolumn{5}{|c|}{$\operatorname{LDG}\left(\mathrm{J} / \mathrm{cm}^{2}\right)$} \\
\hline & & $7.2^{\mathrm{a}}$ & $14.4^{\mathrm{b}}$ & $28.8^{c}$ & $57.6^{\mathrm{d}}$ & $115.2^{\mathrm{e}}$ \\
\hline G0/G1 & $83.4 \pm 1.01$ & $84.4 \pm 0.65$ & $84.6 \pm 0.36$ & $84.4 \pm 1.59$ & $92.7 \pm 0.97^{\Delta}$ & $93.9 \pm 0.63^{\Delta}$ \\
\hline S & $9.08 \pm 0.28$ & $10.7 \pm 0.72^{\triangle}$ & $12.3 \pm 0.91^{\Delta}$ & $13.1 \pm 1.09^{\Delta}$ & $6.30 \pm 1.07^{\Delta}$ & $4.90 \pm 0.65^{\Delta}$ \\
\hline $\mathrm{G} 2+\mathrm{M}$ & $6.63 \pm 0.89$ & $4.18 \pm 0.38^{\Delta}$ & $2.60 \pm 0.55^{\Delta}$ & $1.68 \pm 0.37^{\Delta}$ & $0.73 \pm 0.28^{\Delta}$ & $0.63 \pm 0.22^{\Delta}$ \\
\hline
\end{tabular}

$\triangle P<0.01$, compared with SIG, proportion of G0/G1 phase, S phase, and G2/M phase of fibroblasts of each LDG differences were extremely significant $\left(t_{\mathrm{a}}\right.$ were $-3.440,3.280, t_{\mathrm{b}}$ were $-9.662,7.319, t_{\mathrm{c}}$ were $-4.025,9.316, t_{\mathrm{d}}$ were $-5.788,10.78,23.44$, $t_{\mathrm{e}}$ were $\left.-7.461,10.58,4.869\right)$; linear regression analysis, the cell cycle distribution of the low-dose group were closely related to cumulative doses of UVA irradiation, respectively, $r=0.906, F=30.68, P<0.001$.

One-way ANOVA, the proportions of respective phases of cell cycle showed no difference among the $7.2 \mathrm{~J} / \mathrm{cm}^{2}, 14.4 \mathrm{~J} / \mathrm{cm}^{2}$, and $28.8 \mathrm{~J} / \mathrm{cm}^{2}$ dosages, $P>0.05$; The $t$-test also showed no difference between the dosages of $57.6 \mathrm{~J} / \mathrm{cm}^{2}$ and $115.2 \mathrm{~J} / \mathrm{cm}^{2}, P>0.05$.

Detection also showed that the apoptosis peak was markedly observed in the fibroblasts of HDG after $12 \mathrm{~h}$ irradiation. After preirradiation with low-dose UVA irradiation at $7.2,14.4,28.8,57.6$, and $115.2 \mathrm{~J} / \mathrm{cm}^{2}$, respectively, and then subjected to UVA irradiation at $86.4 \mathrm{~J} / \mathrm{cm}^{2}$ in $6 \mathrm{~h}, 12 \mathrm{~h}, 24 \mathrm{~h}$, $48 \mathrm{~h}, 72 \mathrm{~h}, 7 \mathrm{~d}$, and $14 \mathrm{~d}$, the proportion of apoptotic cells in every ARG showed differential decrease, relative to the accumulated dose of low-dose preirradiation and time interval of subsequent high-dose irradiation. With $86.4 \mathrm{~J} / \mathrm{cm}^{2}$ UVA irradiation following single $7.2 \mathrm{~J} / \mathrm{cm}^{2}$ UVA preirradiation, proportions of necrosis and apoptosis decrease in ARG cells of 6-h phase were assayed. But the effects vanished in 12-h phase. Low-dose preirradiation accumulated to over $28.8 \mathrm{~J} / \mathrm{cm}^{2}$, necrosis and apoptosis were still reduced even at $14 \mathrm{~d}$ with high-dose irradiation. Simultaneously, after low dose preirradiation, the extent of necrosis and apoptosis was reduced by preirradiation. When the cumulative dose was less than $57.6 \mathrm{~J} / \mathrm{cm}^{2}$, the effect was directly proportional to the low cumulative dose. However, the response was weak with the cumulative preirradiation dose up to $115.2 \mathrm{~J} / \mathrm{cm}^{2}$ [34]. The degree of necrosis and apoptosis in different groups was assayed quantitatively by AnnexinV/PI staining. Apoptosis and necrosis were caused by different cumulative doses of preirradiation and high-dose irradiation at different time points subsequently. The results of this radiation effect were shown in Figure 5. Changes in apoptosis in every group were caused by high- dose irradiation at different time intervals after different cumulative doses of preirradiation. The static assayed result was expressed in Table 3.

\subsection{Low-Dose UVA Preirradiation Conferred DNA Protec-} tive Effects, against Subsequent Lethal-Dose UVA Exposure. Single-cell gel electrophoresis (SCGE) was carried out on every group $30 \mathrm{~min}$ after UVA irradiation. After $5 \mu \mathrm{g} / \mathrm{mL}$ ethidium bromide dyeing, the orange-yellow cells were observed under fluorescence microscope. Four types were identified as follows. (1) Type I: undamaged, with no obvious tail; (2) type II: with a tail shorter than the diameter of the head (nucleus); (3) type III: with a tail longer but less wider than the diameter of the head; (4) type IV: with a tail longer and wider than the diameter of the head (Figure 6). Table 4 shows the proportion of DNA migration in cultured fibroblasts and the diameter and the length of DNA migration in the comet assay. The proportion of DNA migration in cultured fibroblasts was $6.50 \%$. The length of
DNA migration in cultured cells was $110.7 \pm 4.00(\mu \mathrm{m})$. Significant differences in DNA migration and the length of DNA migration with different cumulative doses in RAG and single HDG after $6 \mathrm{~h}$ with low-dose preirradiation were determined by $t$-test. A positive correlation between DNA protection and the accumulated dose were observed.

\section{Discussion}

In the present study, we demonstrated the changes in morphology, cell cycle, apoptosis and DNA damage due to low-dose UVA-irradiation on dermal fibroblasts and the protective effects of low-dose UVA preirradiation that prevented the cultured dermal fibroblasts from damage caused by subsequent lethal-dose UVA irradiation.

The LI used in PBM might be low intensity LI (LIL) (about $\left.10 \mathrm{~mW} / \mathrm{cm}^{2}\right)$, or moderate intensity LI (MIL) $\left(10^{2} \sim\right.$ $10^{3} \mathrm{~mW} / \mathrm{cm}^{2}$ ) [8, 35]. The UVA at $60 \mathrm{~mW} / \mathrm{cm}^{2}$ in our experiments was a kind of MIL which PBM is mediated by ROS [8]. The PBM on a function is dependent on whether it is in its function-specific homeostasis (FSH). FSH is just a negative feedback response for a function to be fully performed. There is no PBM of MIL for short irradiation time on a function in its FSH, but MIL for long irradiation time can disrupt a FSH [8]. The survival rate of fibroblasts was not affected significantly with $7.2 \mathrm{~J} / \mathrm{cm}^{2}, 14.4 \mathrm{~J} / \mathrm{cm}^{2}$, and $28.8 \mathrm{~J} / \mathrm{cm}^{2}$ UVA. At a dose above $43.2 \mathrm{~J} / \mathrm{cm}^{2}(\geq 720 \mathrm{~s})$, cell survival rate obviously decreased in a dose-dependent fashion: the survival rate of fibroblasts was 19.7 percent after exposure to $86.4 \mathrm{~J} / \mathrm{cm}^{2}$ UVA for 24 hours. The fibroblasts in $10 \%$ FCS were in proliferation-specific homeostasis (PSH) so that the UVA at $7.2 \mathrm{~J} / \mathrm{cm}^{2}, 14.4 \mathrm{~J} / \mathrm{cm}^{2}$ and $28.8 \mathrm{~J} / \mathrm{cm}^{2}$ cannot modulate the proliferation $[8,36,37]$. The UVA at increased doses disrupted the $\mathrm{PSH}$, causing extensive, dose-dependent inhibition or cell death. Therefore, in our experiments, low-dose UVA was termed as a dose that does not affect morphology and growth of fibroblasts. Cultured dermal fibroblasts were irradiated with a low-dose $7.2 \mathrm{~J} / \mathrm{cm}^{2}$ UVA preirradiation and by a subsequent lethal dose of 86.4 $\mathrm{J} / \mathrm{cm}^{2}$ UVA.

Cellular morphology and proliferation of cultured dermal fibroblasts treated with single irradiation of $7.2 \mathrm{~J} / \mathrm{cm}^{2}$ UVA were not altered, but when irradiation dosage increased to more than $28.8 \mathrm{~J} / \mathrm{cm}^{2}$, cells showed dose-dependent inhibition of proliferation. With further low-dose UVA 


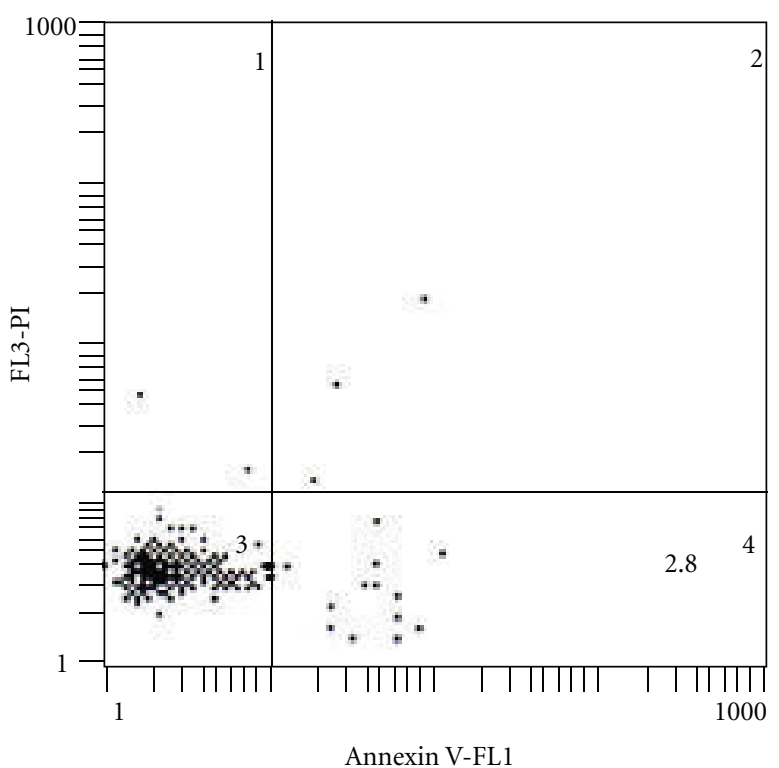

(a)

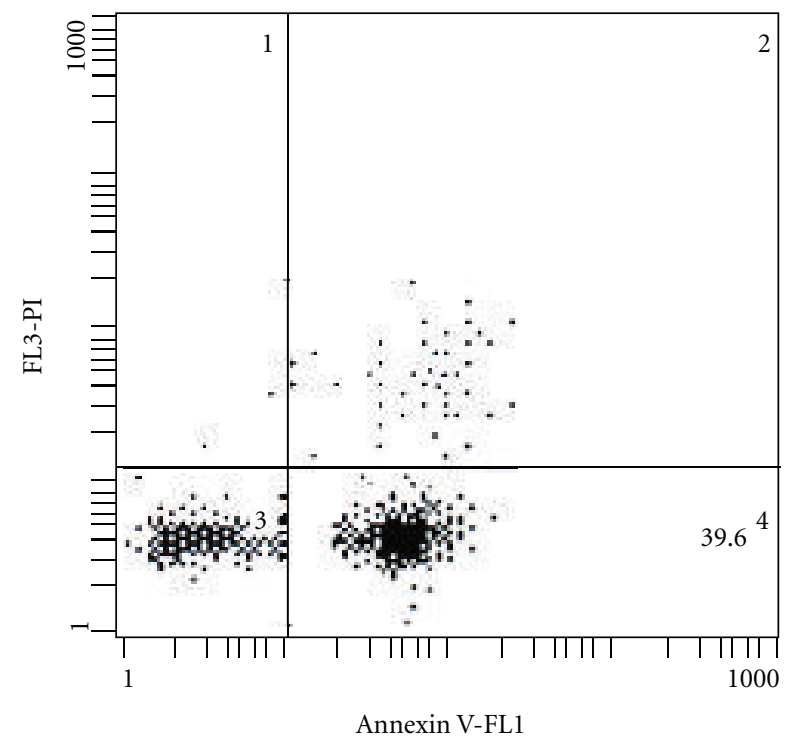

(c)

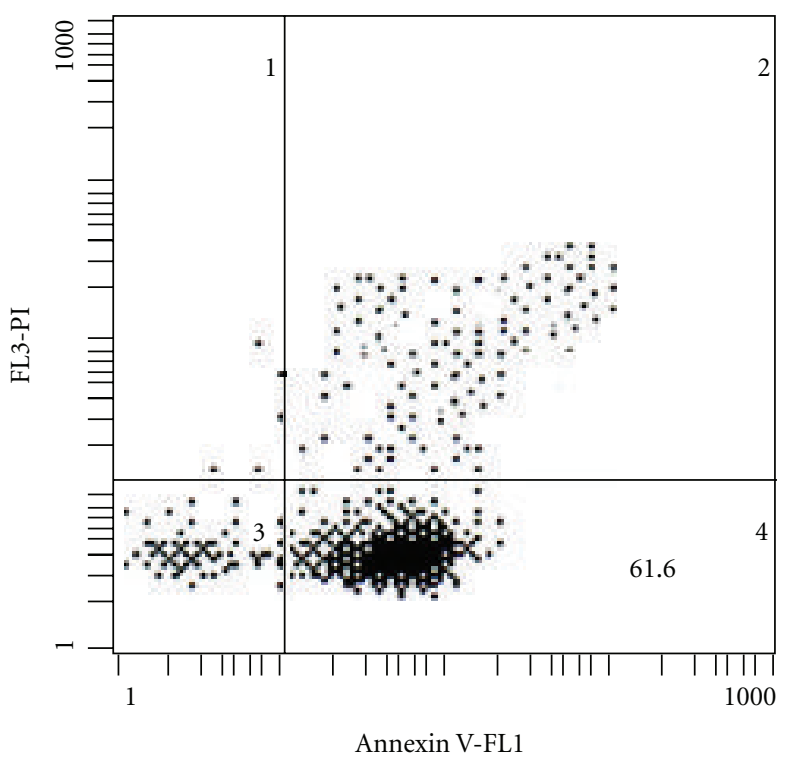

(b)

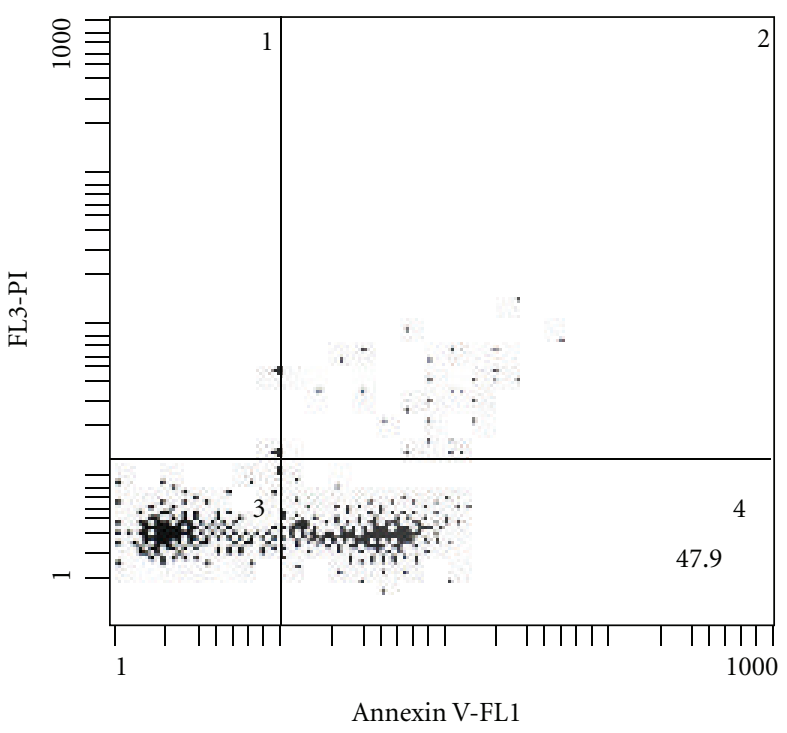

(d)

FIGURE 5: Detection of apoptosis in fibroblasts by flow cytometry. (a) Most of the fibroblasts in the SIG were alive, with only 2.8\% of apoptotic cells. (b) The high-dose UVA irradiation $\left(86.4 \mathrm{~J} / \mathrm{cm}^{2}\right)$ strongly induced cellular apoptosis in cultured fibroblasts, with $61.6 \%$ apoptotic cells. ( $c$ and d) Preirradiation of low-dose UVA reduced cellular apoptosis induced by the subsequent lethal dose of UVA irradiation. Irradiation with $86.4 \mathrm{~J} / \mathrm{cm}^{2}$ UVA $6 \mathrm{~h}$ and $72 \mathrm{~h}$ after preirradiation with a cumulative dose of $28.8 \mathrm{~J} / \mathrm{cm}^{2}$, reduced the proportion of apoptotic cells to $39.6 \%(\mathrm{c})$, and $47.9 \%(\mathrm{~d})$, respectively.

irradiation exposure, fibroblasts showed characteristic morphological and cytological changes in cellular senescence such as delayed doubling time and enlarged cell volume, cellular granulation, augmented volume of mitochondria and so on. Massive apoptosis and death of $86.4 \mathrm{~J} / \mathrm{cm}^{2}$ UVAirradiated cultured cells were observed after $3 \mathrm{~h}$ and reached a peak about $12 \mathrm{~h}$, showing evidence of acute toxic reaction. In the ARG, the low-dose UVA preirradiation relieved toxic response in morphology induced by the subsequent lethal dose of UVA irradiation. Interestingly, the fibroblasts of LDG not only displayed plenty of RER (rough endoplasmic reticulum) that suggested decreased cell synthesis, but also features of cellular senescence with further exposure to lowdose UVA irradiation. These results showed that repeated exposure of human fibroblasts to low-dose UVA induced fibroblast senescence [38], but also suggested that senescence might be some kind of adaptive response induced by lowdose UVA irradiation, serving as a cellular mechanism to escape from stress-induced death.

Apoptosis or programmed cell death is a key function in regulating skin development, homeostasis, and tumorigenesis [39]. UV-triggered apoptotic signaling has been 
TABLE 3: Effects of lethal irradiation on fibroblast apoptosis after UVA preirradiation at different time intervals $(x \pm S \%, n=4)$.

\begin{tabular}{|c|c|c|c|c|c|c|c|}
\hline \multirow{2}{*}{ Group/time } & \multirow{2}{*}{ SIG } & \multirow{2}{*}{$\mathrm{HDG}^{\mathrm{a}}$} & \multicolumn{5}{|c|}{$\operatorname{ARG}\left(\mathrm{J} / \mathrm{cm}^{2}\right)$} \\
\hline & & & 7.2 & 14.4 & 28.8 & 57.6 & 115.2 \\
\hline $3 \mathrm{~h}$ & $2.38 \pm 0.47$ & $55.3 \pm 6.17$ & $50.2 \pm 4.15^{b}$ & $35.0 \pm 4.87^{c}$ & $39.4 \pm 2.21^{\mathrm{d}}$ & $35.2 \pm 3.82^{\mathrm{e}}$ & $37.3 \pm 3.95^{\mathrm{f}}$ \\
\hline $6 \mathrm{~h}$ & $2.68 \pm 0.33$ & $54.7 \pm 4.11$ & $49.3 \pm 4.92^{\mathrm{b}}$ & $42.5 \pm 3.93^{c}$ & $43.9 \pm 3.33^{\mathrm{d}}$ & $38.5 \pm 2.87^{\mathrm{e}}$ & $41.4 \pm 3.02^{\mathrm{f}}$ \\
\hline $12 \mathrm{~h}$ & $2.60 \pm 0.56$ & $61.9 \pm 6.47$ & $55.4 \pm 9.26$ & $41.1 \pm 3.61^{\mathrm{c}}$ & $45.6 \pm 1.05^{\mathrm{d}}$ & $42.0 \pm 1.15^{\mathrm{e}}$ & $43.4 \pm 4.09^{\mathrm{f}}$ \\
\hline $24 \mathrm{~h}$ & $2.70 \pm 0.27$ & $59.0 \pm 2.81$ & $55.7 \pm 6.29$ & $47.8 \pm 9.71^{\mathrm{c}}$ & $47.9 \pm 4.65^{\mathrm{d}}$ & $45.9 \pm 5.45^{\mathrm{e}}$ & $44.8 \pm 2.66^{\mathrm{f}}$ \\
\hline $48 \mathrm{~h}$ & $2.78 \pm 0.25$ & $55.3 \pm 5.36$ & $52.9 \pm 3.77$ & $56.1 \pm 6.00$ & $49.0 \pm 6.35^{\mathrm{d}}$ & $48.2 \pm 3.34^{\mathrm{e}}$ & $44.1 \pm 2.95^{\mathrm{f}}$ \\
\hline $72 \mathrm{~h}$ & $2.68 \pm 0.33$ & $57.0 \pm 3.60$ & $57.5 \pm 4.19$ & $54.8 \pm 5.19$ & $45.2 \pm 4.22^{\mathrm{d}}$ & $49.2 \pm 2.44^{\mathrm{e}}$ & $45.9 \pm 3.40^{\mathrm{f}}$ \\
\hline $7 \mathrm{~d}$ & $2.25 \pm 0.45$ & $59.4 \pm 5.78$ & $58.1 \pm 7.04$ & $56.6 \pm 9.56$ & $46.8 \pm 7.94^{\mathrm{d}}$ & $48.4 \pm 2.44^{\mathrm{e}}$ & $46.6 \pm 3.71^{\mathrm{f}}$ \\
\hline $14 \mathrm{~d}$ & $2.10 \pm 0.46$ & $61.4 \pm 3.53$ & $55.1 \pm 3.36$ & $60.5 \pm 8.16$ & $48.3 \pm 6.34^{\mathrm{d}}$ & $47.3 \pm 3.82^{\mathrm{e}}$ & $46.8 \pm 4.72^{\mathrm{f}}$ \\
\hline
\end{tabular}

${ }^{\mathrm{a}} P<0.001$, compared with SIG, differences were significant $(t=-53.52),{ }^{\mathrm{b}} P<0.01$, compared with HDG, differences in corresponding phase points were significant $(t=13.68,16.34),{ }^{\mathrm{C}} \mathrm{P}<0.01$, compared with HDG, differences in corresponding phase points were significant $\left(t_{3 \mathrm{~h}}=18.84, t_{6 \mathrm{~h}}=13.00\right.$, $\left.t_{12 \mathrm{~h}}=4.645\right) ;{ }^{\mathrm{d}} P<0.01$, compared with HDG, differences in corresponding phase points were significant $(t$ value in phases, resp., were 7.654, 12.64, 17.69, $21.24,14.81,13.21$, and 15.84); ${ }^{e} P<0.01$, compared with HDG, differences in corresponding phase points were significant $(t$ value in phases, resp., were $5.279,11.63,7.698,13.55,12.85,4.281,4.845$, and 24.88$){ }^{\mathrm{f}} P<0.01$, compared with HDG, differences in corresponding phase points were significant $(t$ value in phases, resp., were 6.774, 7.386, 5.047, 24.02, 3.792, 5.146, 9.548, and 16.49).

One-way ANOVA, the proportion of apoptotic fibroblasts showed no difference among the ARG1 $\left(7.2 \mathrm{~J} / \mathrm{cm}^{2}\right)$, ARG2 $\left(14.4 \mathrm{~J} / \mathrm{cm}^{2}\right)$, and ARG3 $\left(28.8 \mathrm{~J} / \mathrm{cm}^{2}\right)$, $P>0.05 ; t$-test, no difference observed between ARG4 $\left(57.6 \mathrm{~J} / \mathrm{cm}^{2}\right)$ and ARG3 $\left(115.2 \mathrm{~J} / \mathrm{cm}^{2}\right), P>0.05$.

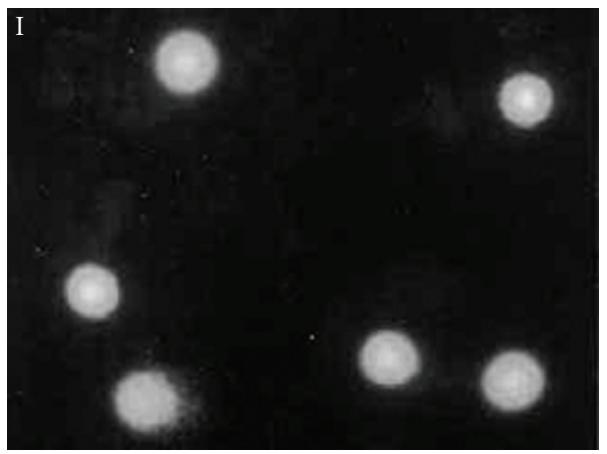

(a)

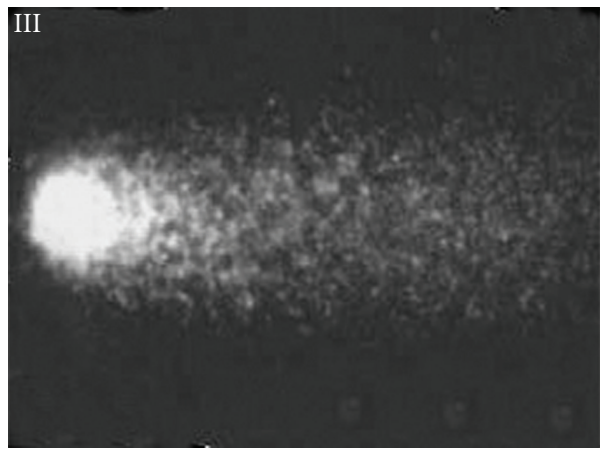

(c)

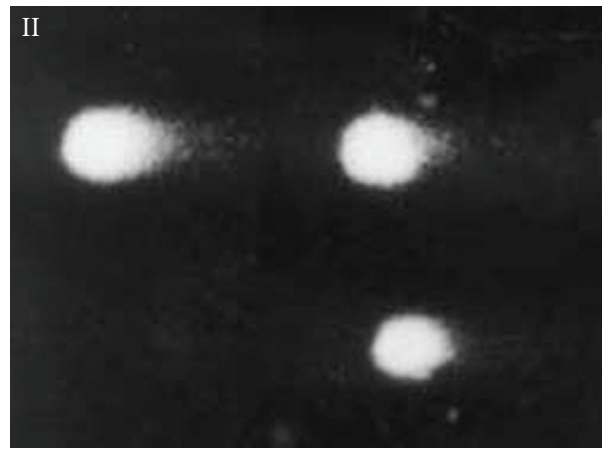

(b)

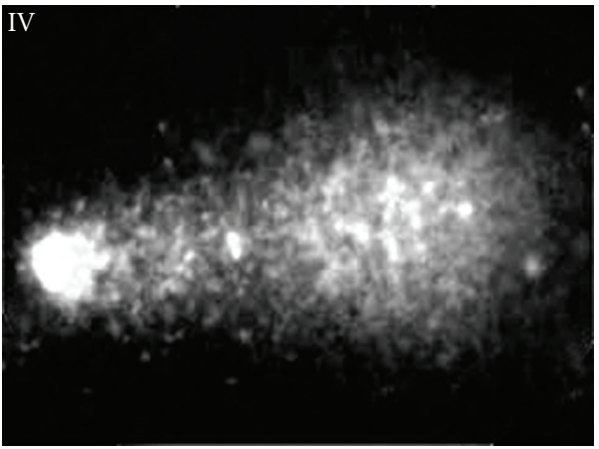

(d)

FIgURE 6: Fluorescence microscopic detection of four types of cellular DNA separated by SCGE. (a) Type I: undamaged, with no obvious tail; (b) type II: with a tail shorter than the diameter of the head (nucleus); (c) type III: with a tail longer but less wider than the diameter of the head; (d) type IV: with a tail length and width both longer than the diameter of the head.

well documented, whereas UV-induced survival effects have received little attention. Our results suggested that lowdose UVA preirradiation induced fibroblast cell cycle arrest, reduced cellular apoptosis induced by the subsequent lethaldose UVA irradiation. In the low-dose group, the proportion of fibroblasts in the G0/G1 phase and in the S phase was increased with the cumulative dose addition after single low-dose UVA irradiation once a day, but no differences among fibroblasts of LDG1 $\left(7.2 \mathrm{~J} / \mathrm{cm}^{2}\right)$, LDG2 $\left(14.4 \mathrm{~J} / \mathrm{cm}^{2}\right)$ and LDG3 $\left(28.8 \mathrm{~J} / \mathrm{cm}^{2}\right)$ were observed. It might suggest that fibroblasts cultured in $10 \%$ FCS were in $\mathrm{PSH}$, but with the dosages increasing to $57.6 \mathrm{~J} / \mathrm{cm}^{2}$ and $115.2 \mathrm{~J} / \mathrm{cm}^{2}$, fibroblasts were arrested in the G0/G1 phase, cell synthesis and proliferation were inhibited remarkably, which suggested 
TABLE 4: Effects of low-dose UVA preirradiation on fibroblast DNA damage $(x \pm S, n=4)$.

\begin{tabular}{|c|c|c|c|c|c|}
\hline \multicolumn{2}{|l|}{ Groups } & The percentage of DNA migration (\%) & $t$ value & Average length of DNA migration $(\mu \mathrm{m})$ & $t$ value \\
\hline \multicolumn{2}{|l|}{ SIG } & $7.50 \pm 1.29$ & & $11.8 \pm 3.49$ & \\
\hline \multicolumn{2}{|l|}{ HDG } & $90.8 \pm 4.35^{\bullet \bullet}$ & -36.41 & $102 \pm 29.4^{\bullet \bullet}$ & -11.98 \\
\hline \multirow{5}{*}{$\operatorname{ARG}\left(J / \mathrm{cm}^{2}\right)$} & 7.2 & $82.5 \pm 6.81^{\triangle}$ & 3.794 & $88.4 \pm 19.1$ & 1.596 \\
\hline & 14.4 & $75.0 \pm 2.94^{\triangle}$ & 10.97 & $77.3 \pm 19.6^{\triangle}$ & 12.78 \\
\hline & 28.8 & $68.5 \pm 3.87^{\Delta \Delta}$ & 11.52 & $65.3 \pm 18.5^{\Delta \Delta}$ & 14.38 \\
\hline & 57.6 & $57.9 \pm 5.38^{\Delta}$ & 8.568 & $49.3 \pm 14.5^{\Delta \Delta}$ & 16.76 \\
\hline & 115.2 & $51.0 \pm 5.48^{\triangle}$ & 10.93 & $42.9 \pm 11.4^{\Delta \Delta}$ & 17.90 \\
\hline
\end{tabular}

$t$-test, compared with SIG, differences were extremely significant ${ }^{\circ} P<0.001$; compared with HDG, differences were extremely significant $\Delta \Delta P<0.001$, and significant ${ }^{\triangle} P<0.01$; linear regression analysis of internal ARG, the percentage of DNA migration $(r=0.764, F=25.25, t=-5.025$, and $P<0.001)$ and average length of DNA migration $(r=0.603, F=44.55, t=-6.674$, and $P<0.001)$ were both close related to accumulated doses.

One-way ANOVA, the percentage of DNA migration, and the average length of DNA migration were no different among the ARG1 (7.2 J/cm $\left.{ }^{2}\right)$, ARG2 $\left(14.4 \mathrm{~J} / \mathrm{cm}^{2}\right)$, and ARG3 $\left(28.8 \mathrm{~J} / \mathrm{cm}^{2}\right), P>0.05 ; t$-test, there also was no difference between ARG4 $\left(57.6 \mathrm{~J} / \mathrm{cm}^{2}\right)$ and ARG3 $\left(115.2 \mathrm{~J} / \mathrm{cm}^{2}\right), P>0.05$.

that fibroblasts were in resting-specific homeostasis [8] that was better than PSH in resisting apoptosis of fibroblasts induced by a lethal dose of UVA irradiation.

UVA mainly produces ROS through interaction with endogenous photosensitizers. These ROS can in turn damage DNA indirectly $[24,25]$. It was established that UVA irradiation was most likely to cause single-strand breaks in fibroblast DNA [40]. The SCGE was therefore used to detect the DNA damage caused by UVA in our study. Single-strand DNA breaks in fibroblasts were likely to reach their peak $1 \mathrm{~h}$ after UVA irradiation, and therefore immediately subjected to SCGE [27]. Our results showed that, compared with SIG, no further DNA damage of human skin fibroblasts exposed to low-dose UVA radiation as detected by SCGE. The low dose UVA preirradiation induced significant protective effects against DNA damage associated with the subsequent lethal dose of UVA irradiation, with $7.2 \mathrm{~J} / \mathrm{cm}^{2}, 14.4 \mathrm{~J} / \mathrm{cm}^{2}$ and $28.8 \mathrm{~J} / \mathrm{cm}^{2}(P<0.05)$ or between $57.6 \mathrm{~J} / \mathrm{cm}^{2}$ and $115.2 \mathrm{~J} / \mathrm{cm}^{2}$ $(P<0.05)$. The mechanisms might involve DNA repair and temporary cell cycle arrest induced by low-dose UVA irradiation. This protective response not only inhibited the damage, but also increased the resilience of cells against a subsequent UV dose, leading to increased survival of cells that maintain their DNA repair capability [23].

The beneficial effects of ultraviolet radiation on human are well known. In recent years, growing epidemiological evidence suggests that exposure to ultraviolet radiation may decrease risk for a number of serious cancers including prostate cancer. The beneficial biological effects may be associated with PBM induced by low-dose irradiation. Further research on PBM including adaptive responses may have great medical significance in terms of exposure to ultraviolet radiation.

\section{Conclusions}

Our results suggested that low-dose UVA radiation might induce adaptive response protecting cultured dermal fibroblasts from damage due to subsequent lethal dose of UVA. The degree of protection and duration of the response might be clearly related to the accumulated doses of low-dose UVA radiation.

\section{Acknowledgments}

This work was supported by the National Natural Science Foundation of China (Grant no. 30972652), and the National Natural Science Foundation of Guangdong Province (Grant no. 915100100200020). Liu and his collaborators report no conflicts of interest relating to any manufacturers or distributors in this paper. The authors would also like to thank Professor Timon Chengyi LIU for his excellent and professional revision of this paper.

\section{References}

[1] A. P. Moczek, S. Sultan, S. Foster et al., "The role of developmental plasticity in evolutionary innovation," Proceedings of the Royal Society B, vol. 278, no. 1719, pp. 2705-2713, 2011.

[2] M. P. Mattson, "Hormesis defined," Ageing Research Reviews, vol. 7, no. 1, pp. 1-7, 2008.

[3] S. Tapio and V. Jacob, "Radioadaptive response revisited," Radiation and Environmental Biophysics, vol. 46, no. 1, pp. 112, 2007.

[4] L. A. Sagan, G. Chairman, and J. J. Cohen, "Biological effects of low-dose radiation: overview and perspective," Health Physics, vol. 59, no. 1, pp. 11-13, 1990.

[5] M. Pollycove and L. E. Feinendegen, "Radiation-induced versus endogenous DNA damage: possible effect of inducible protective responses in mitigating endogenous damage," Human and Experimental Toxicology, vol. 22, no. 6, pp. 290306, 2003.

[6] S. Z. Liu, "Biological effects of low level exposures to ionizing radiation: theory and practice," Human and Experimental Toxicology, vol. 29, no. 4, pp. 275-281, 2010.

[7] J. Fu, C. G. Woods, E. Yehuda-Shnaidman et al., "Lowlevel arsenic impairs glucose-stimulated insulin secretion in pancreatic beta cells: involvement of cellular adaptive response to oxidative stress," Environmental Health Perspectives, vol. 118, no. 6, pp. 864-870, 2010.

[8] T. C. Y. Liu, R. Liu, L. Zhu, J. Q. Yuan, M. Hu, and S. H. Liu, "Homeostatic photobiomodulation," Frontiers of Optoelectronics in China, vol. 2, no. 1, pp. 1-8, 2009.

[9] M. J. Conlan, "Biostimulation of wound healing by low-energy laser irradiation: a review," Journal of Clinical Periodontology, vol. 23, no. 5, pp. 492-496, 1996.

[10] G. A. Guzzardella, M. Fini, P. Torricelli, G. Giavaresi, and R. Giardino, "Laser stimulation on bone defect healing: an in 
vitro study," Lasers in Medical Science, vol. 17, no. 3, pp. 216 220, 2002.

[11] N. Cohen, R. Lubart, S. Rubinstein, and H. Breitbart, "Light irradiation of mouse spermatozoa: stimulation of in vitro fertilization and calcium signals," Photochemistry and Photobiology, vol. 68, no. 3, pp. 407-413, 1998.

[12] M. Kreisler, A. B. Christoffers, H. Al-Haj, B. Willershausen, and B. D'Hoedt, "Low level 809-nm diode laser-induced in vitro stimulation of the proliferation of human gingival fibroblasts," Lasers in Surgery and Medicine, vol. 30, no. 5, pp. 365-369, 2002.

[13] N. Grossman, N. Schneid, H. Reuveni, S. Halevy, and R. Lubart, "780 nm low power diode laser irradiation stimulates proliferation of keratinocyte cultures: involvement of reactive oxygen species," Lasers in Surgery and Medicine, vol. 22, no. 4, pp. 212-218, 1998.

[14] J. S. Chen, H. C. Chiu, C. J. Hsu et al., "Low-energy visible light irradiation modulates immune responses induced by epicutaneous sensitization with protein antigen," Journal of Investigative Dermatology, vol. 129, no. 9, pp. 2258-2264, 2009.

[15] V. Molho-Pessach and M. Lotem, "Ultraviolet radiation and cutaneous carcinogenesis," Current Problems in Dermatology, vol. 35, pp. 14-27, 2007.

[16] L. P. Massari, M. Kaštelan, and F. Gruber, "Epidermal malignant tumors: pathogenesis, influence of UV light and apoptosis," Collegium Antropologicum, vol. 31, no. 1, pp. 8385, 2007.

[17] T. Henriksen, A. Dahlback, S. H. Larsen, and J. Moan, "Ultraviolet-radiation and skin cancer. Effect of an ozone layer depletion," Photochemistry and photobiology, vol. 51, no. 5, pp. 579-582, 1990.

[18] D. Bodiwala, C. J. Luscombe, S. Liu et al., "Prostate cancer risk and exposure to ultraviolet radiation: further support for the protective effect of sunlight," Cancer Letters, vol. 192, no. 2, pp. 145-149, 2003.

[19] M. F. McCarty, "A moderately low phosphate intake may provide health benefits analogous to those conferred by UV light-a further advantage of vegan diets," Medical Hypotheses, vol. 61, no. 5-6, pp. 543-560, 2003.

[20] W. P. Jeeves and A. J. Rainbow, "U.V. enhanced reactivation of U.V.- and $\gamma$-irradiated adenovirus in normal human fibroblasts," International Journal of Radiation Biology, vol. 43, no. 6, pp. 599-623, 1983.

[21] H. S. Murphy, V. A. Palejwala, M. Sayeedur Rahman, P. M. Dunman, G. Wang, and M. Zafri Humayun, "Role of mismatch repair in the Escherichia coli UVM response," Journal of Bacteriology, vol. 178, no. 23, pp. 6651-6657, 1996.

[22] G. E. Costin and V. J. Hearing, "Human skin pigmentation: melanocytes modulate skin color in response to stress," FASEB Journal, vol. 21, no. 4, pp. 976-994, 2007.

[23] D. Decraene, K. Smaers, D. Maes, M. Matsui, L. Declercq, and M. Garmyn, "A low UVB dose, with the potential to trigger a protective $\mathrm{p} 53$-dependent gene program, increases the resilience of keratinocytes against future UVB insults," Journal of Investigative Dermatology, vol. 125, no. 5, pp. 10261031, 2005.

[24] K. Scharffetter-Kochanek, M. Wlaschek, P. Brenneisen, M. Schauen, R. Blaudschun, and J. Wenk, "UV-induced reactive oxygen species in photocarcinogenesis and photoaging," Biological Chemistry, vol. 378, no. 11, pp. 1247-1257, 1997.

[25] W. Ma, M. Wlaschek, I. Tantcheva-Poór et al., "Chronological ageing and photoageing of the fibroblasts and the dermal connective tissue," Clinical and Experimental Dermatology, vol. 26, no. 7, pp. 592-599, 2001.

[26] K. Kaji, T. Ohta, N. Horie, E. Naru, M. Hasegawa, and N. Kanda, "Donor age reflects the replicative lifespan of human fibroblasts in culture: research article," Human Cell, vol. 22, no. 2, pp. 38-42, 2009.

[27] N. Emonet-Piccardi, M. J. Richard, J. L. Ravanat, N. Signorini, J. Cadet, and J. C. Béani, "Protective effects of antioxidants against UVA-induced DNA damage in human skin fibroblasts in culture," Free Radical Research, vol. 29, no. 4, pp. 307-313, 1998.

[28] K. Maier, R. Schmitt-Landgraf, and B. Siegemund, "Development of an in vitro test system with human skin cells for evaluation of phototoxicity," Toxicology in Vitro, vol. 5, no. 56, pp. 457-461, 1991.

[29] M. Chen, G. Zhang, M. Yi et al., "Effect of UVA irradiation on proliferation and NO/iNOS system of human skin fibroblast," Journal of Central South University, vol. 34, no. 8, pp. 705-711, 2009.

[30] A. Schindl, G. Klosner, H. Hönigsmann, G. Jori, P. C. Calzavara-Pinton, and F. Trautinger, "Flow cytometric quantification of UV-induced cell death in a human squamous cell carcinoma-derived cell line: cose and kinetic studies," Journal of Photochemistry and Photobiology B, vol. 44, no. 2, pp. 97106, 1998.

[31] C. Alapetite, T. Wachter, E. Sage, and E. Moustacchi, "Use of the alkaline comet assay to detect DNA repair deficiencies in human fibroblasts exposed to UVC, UVB, UVA and $\gamma$-rays," International Journal of Radiation Biology, vol. 69, no. 3, pp. 359-369, 1996.

[32] J. D. Hoerter, C. S. Ward, K. D. Bale et al., "Effect of UVA fluence rate on indicators of oxidative stress in human dermal fibroblasts," International Journal of Biological Sciences, vol. 4, no. 2, pp. 63-70, 2008.

[33] H. Bånrud, T. Stokke, J. Moan, and K. Berg, "S phase arrest and induction of multinucleated cells after exposure to ultraviolet radiation," Carcinogenesis, vol. 16, no. 5, pp. 1087-1094, 1995.

[34] Y. Ibuki and R. Goto, "Antiapoptotic effects induced by different wavelengths of ultraviolet light," Photochemistry and Photobiology, vol. 75, no. 5, pp. 495-502, 2002.

[35] S. S. Campbell and P. J. Murphy, "Extraocular circadian phototransduction in humans," Science, vol. 279, no. 5349, pp. 396-399, 1998.

[36] T. C. Y. Liu, J. L. Jiao, X. Y. Xu, X. G. Liu, S. X. Deng, and S. H. Liu, "Photobiomodulation: phenomenology and its mechanism," in Optics in Health Care and Biomedical Optics: Diagnostics and Treatment II, Proceedings of the SPIE, pp. 185-191, chn, November 2004.

[37] X. H. Yang, C. Y. Liu, S. J. Liu et al., "Photobiomodulation on chondrocyte proliferation: in vitro evaluation," Zhongguo Jiguang/Chinese Journal of Lasers, vol. 33, no. 12, pp. 16921698, 2006.

[38] J. Shin, J. H. Kim, and E. K. Kim, "Repeated exposure of human fibroblasts to UVR induces secretion of stem cell factor and senescence," Journal of the European Academy of Dermatology and Venereology. In press.

[39] N. Pustišek and M. Šitum, "UV-radiation, apoptosis and skin," Collegium Antropologicum, vol. 35, no. 2, supplement 2, pp. 339-341, 2011.

[40] J. L. Rizzo, J. Dunn, A. Rees, and T. M. Rünger, "No formation of DNA double-strand breaks and no activation of recombination repair with UVA," Journal of Investigative Dermatology, vol. 131, no. 5, pp. 1139-1148, 2011. 


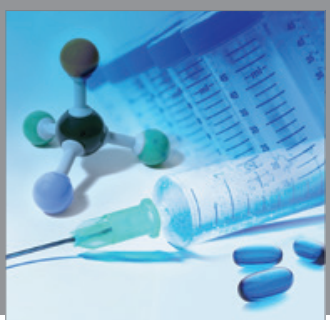

International Journal of

Medicinal Chemistry

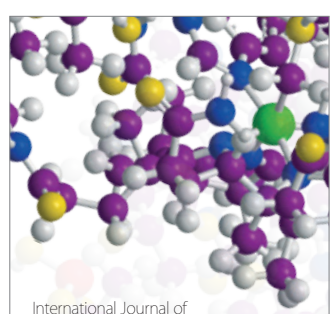

Carbohydrate Chemistry

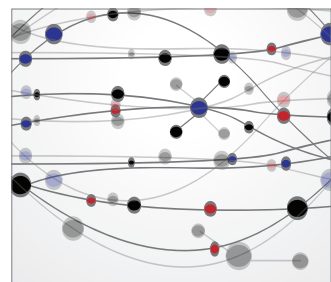

The Scientific World Journal
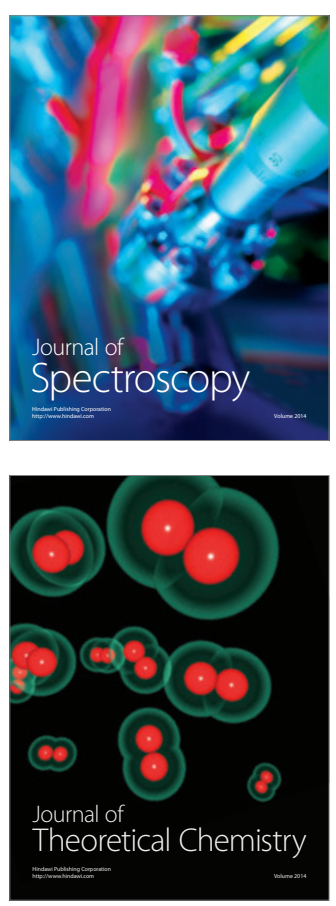
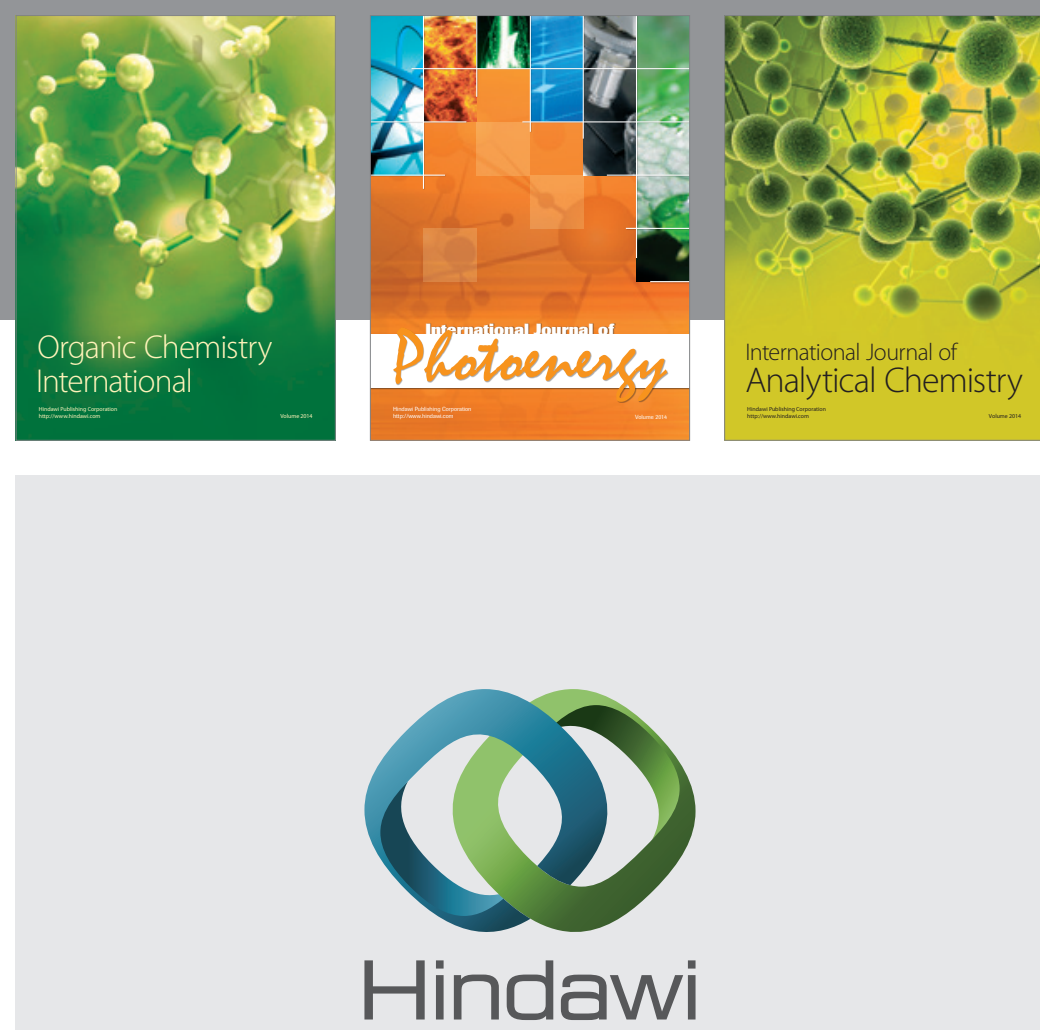

Submit your manuscripts at

http://www.hindawi.com
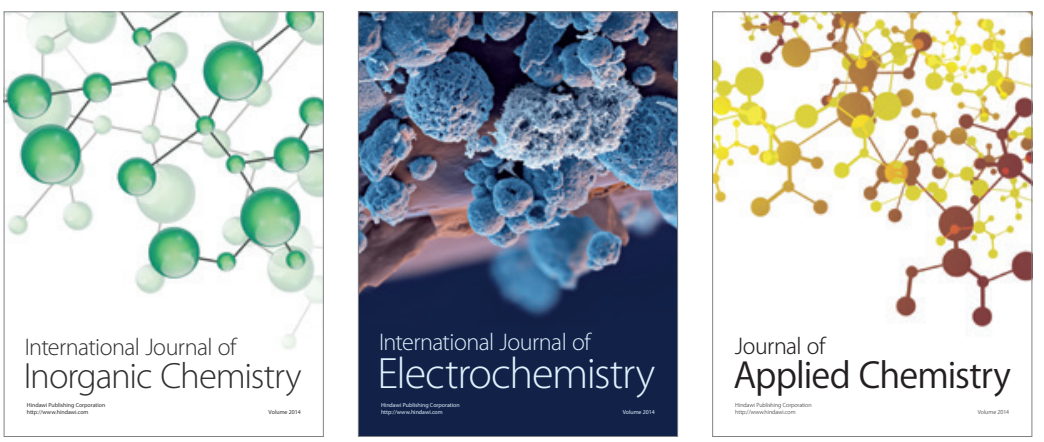

Journal of

Applied Chemistry
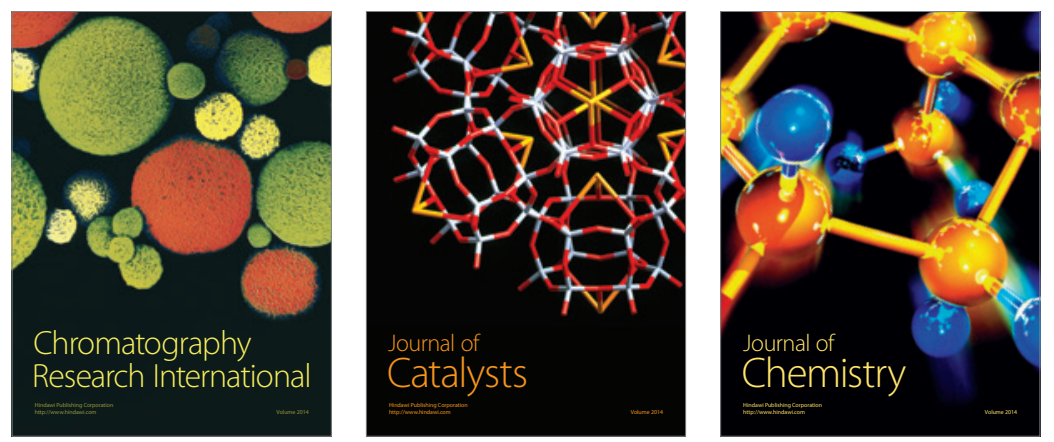
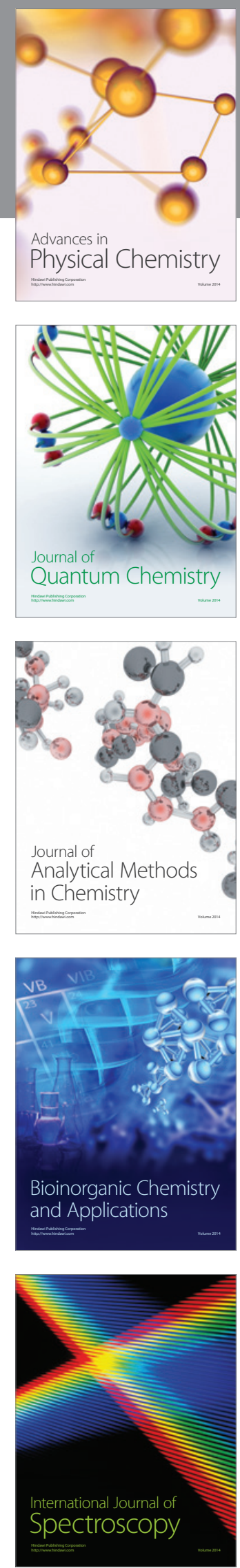